\title{
ОНИМИТЕ ВО РОМАНОТ „ВРЕМЕТО НА КОЗИТЕ“ ОД ЛУАН СТАРОВА И НИВНИТЕ ЕКВИВАЛЕНТИ ВО ПРЕВОДИТЕ НА ГЕРМАНСКИ И НА АНГЛИСКИ ЈАЗИК
}

\author{
Жанета Савиќ \\ Универзитет „Св. Кирил и Методиј“, Скопје \\ zaneta.savik@gmail.com
}

\begin{abstract}
Фокусот на анализата во оваа статија се три класи оними - зоонимите (имињата на животни), антропонимите (имињата на лица) и топонимите (имињата на места), и тоа низ призмата на нивната улога во едно книжевно дело, како и пристапите на нивното предавање, во случајов, на германски и на англиски јазик. Значи, анализата е направена врз корпус од еден роман на македонски јазик и два негови преводи. Поконкретно, предмет на истражување во оваа статија се онимите од македонското книжевно дело „Времето на козите“" од Луан Старова и нивните еквиваленти во преводите на германски, односно на англиски јазик - се анализира нивната функција во книжевноста и проблематиката врзана со трансферот во друг јазик. Поимот еквиваленй, односно, во конкретниот случај, еквивалениш на оним, уште и во книжевно дело, по природата на истражувањето го надминува прототипското системско-лингвистичко толкување на еквиваленцијата (целосна, делумна, нулева еквиваленција), барајќи многу попрецизна класификација на еквивалентите, а со тоа навлегувајќи и во сферите на теоријата на преведувањето. Предметот на истражување во оваа статија не може да се лоцира само во науката за имињата (ономастиката) туку и во пристапот на нивниот трансфер во уметничкокнижевниот контекст, односно во транслатологијата.
\end{abstract}

Клучни зборови: ономастика, зооними, антропоними, топоними, трансфер 


\title{
THE ONYMS IN THE NOVEL THE TIME OF THE GOATS BY LUAN STAROVA AND THEIR EQUIVALENTS IN THE NOVEL'S TRANSLATIONS IN GERMAN AND ENGLISH
}

\author{
Žaneta SaviḰ \\ Ss. Cyril and Methodius University in Skopje \\ zaneta.savik@gmail.com
}

The analysis presented in this paper focuses on three classes of onyms: zoonyms (names of animals), anthroponyms (names of persons) and toponyms (names of places), examined through the prism of their function in a particular literary work, as well as on the approaches underlying their translation, in this case, in German and English. The analysis has been conducted on a corpus compiled from a novel written in Macedonian and two of its translations. Specifically, the subject of this research are the onyms in the Macedonian novel The Time of the Goats by Luan Starova and their equivalents in the novel's translation in German and English: what has been analysed is their function in literature and the challenges arising from their transfer into another language. The term equivalent used in this paper, here primarily referred to as an equivalent of an onym, surpasses the prototypical systemic-linguistic interpretation of the notion of equivalence (complete, partial, null equivalence), especially within a literary work, and demands a substantially more precise classification of the equivalents, thus permeating into the spheres of the theory of translation. Hence, the subject matter of the research in this paper is not restricted to the science of names only, but in the approach underlying their transfer within an artistic literary context as well.

Keywords: onomastics, zoonyms, anthroponyms, toponyms, transfer 


\section{1 Функцијата на онимите во книжевноста ${ }^{1}$}

Основната функција на ономастичката лексика е да биде јазично средство за диференцијација, за идентификација на објективната реалност на ниво на единичното, што во современата писмена форма на македонскиот јазик графички се маркира преку употребата на големата буква.

Но, за разлика од објективно постојниот ономастикон, во кој значењето на имињата може да биде делумно или комплетно исклучено од анализата, во уметничката литература личните имиња често се семантички исполнети со свесна интенција на авторот, со што освен означувачка и диференцијална, добиваат и значенска, поточно стилска функција, која игра значајна улога во неговиот стремеж да ја реализира својата замисла, порака и да го достигне максималното ниво на естетска вредност на делото (сп. Коробар-Белчева 2006: 85).

Фактот што постојат уметнички реалии кои не се навистина егзистентни, е доказ дека уметноста не е буквален одраз на фактите на објективната реалност. „На овој начин експлицитно е нагласена извесната автономност на светот на уметноста што постои преку зборот“ (Ризовски 2002: 19). Ризовски понатаму нагласува дека поради различниот степен на измисленоста на имињата, разликите од ваков вид понекогаш не се забележливи. Имено, писателот може да ги именува своите јунаци со имиња што се сосема слични со некои од постојните во реалниот ономастикон или во уметничката литература.

Значи, имињата во литературата можат да имаат само референцијално значење, но во книжевноста често референцијално значи и сигнификативно значење (signum 'значи нешто, е знак'), односно тие не се случајно избрани од писателот. Така, авторот, веројатно тргнувајќи од библиската конотација на името, со антропонимот Петиар именува лик со цврст карактер, „како карпа““. Впрочем, името на литературниот лик не е само етикета на личноста, во него се испреплетуваат многу значења - оние што се содржани во етимологијата на името, оние што произлегуваат од знаењето за носителот на името и оние што посочуваат на афективно-естетските карактеристики што му ги наметнал авторот на определен лик (сп. Šimunovuč 1976: 242).

Што се однесува до топонимите, пак, Ризовски (2002: 20) истакнува дека и тогаш кога авторите водат сметка да нема совпаѓање на имињата на нивните јунаци со „објективно реалниот антропонимикон“, присуството на постојната топонимија во своите дела го примаат како нешто сосема разбирливо. Ова е многу значајно, зашто недвосмислено укажува на потребата да се следат сите димензии на уметничката стварност при нејзиното споредување со објективната реалност. Секако, одлуката на авторите да употребат ономастикон сличен на објективно постојниот (кој е во тесен асоцијативен однос со него) не е нималку случајна. Имено, тие свесно создаваат илузија за сличноста или за различноста на уметничката со објективната стварност.

\footnotetext{
${ }^{1}$ Упатувам благодарност до проф. д-р Силвана Симоска за несебичната помош при истражувањето.
} 
Топонимијата во книжевните дела во најголем дел и објективно постои и само во ретки случаи станува збор за креација на авторот - впрочем, затоа во следните поглавја предмет на истражување ќе биде функцијата на антропонимите, чиј агенс на именување е токму писателот.

Сепак, вреди да се спомене и дистрибуцијата на топонимите во одбраното дело. Имено, Македонија во рамките на Југословенската Федерација, поконкретно Скопје, освен преку ојконимите Еврејско маало, Козар маало 2 , имињата на објектите Женска гимнназија, Музеј на револуичјайа, дромонимот

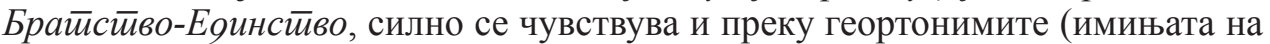

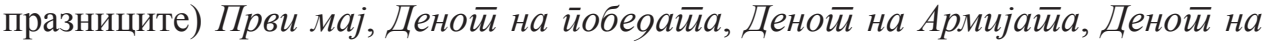
Рейубликайа итн.

Впрочем, конструирањето на просторот, иако најважна, не е единствената функција на топонимите во еден книжевен текст. Така, на пример, топонимите во романите „Времето на козите“ покажуваат дека тие служат и за репрезентација на времето (Michail Bachtin 2008, цитирано според Kohlheim 2017: 360).

\section{1 Онимите во романот „Времето на козите“}

Луан Старова е македонски писател од албанска националност, чии дела во најголем број се напишани токму на македонски јазик. Романот „Времето на козите“ (1993) досега е објавен на десетина јазици, меѓу кои и на германски и на англиски. Има добиено многу номинации и има освоено многу награди за најдобар роман во повеќе земји во Европа, со што се вбројува во едно од неговите најзначајни дела, но истовремено е и роман кој е од голема важност за севкупната македонска книжевност.

Во публикација посветена токму на овој автор и на дел од неговиот богат книжевен опус, Симоска (Simoska 2016) издвојува четири теми што имплицинтно се проткајуваат низ набљудуваните дела („Времето на козите“ и „Ервехе. Книга за една мајка“), и тоа: идентитетот, историјата, егзилот и границите (ibid 125). Ова се теми што ја засегаат не само Македонија или родната земја на Старова, Албанија, туку се, се чини, секогаш актуелни за целиот Балкан, зашто токму на Балканот се преплетуваат различни култури, јазици и религии, па едно такво мултикултурно, мултијазично и мултиконфесионално милје неминовно го отвора прашањето на идентитетот, кој, пак, во овој случај треба да се набљудува како еден културолошки хибрид. Вака дефинираниот идентитет се отсликува и кај протагонистите од повеќе романи на Луан Старова, меѓу кои и кај оние во „Времето на козите“.

Насловот на германскиот превод на романот на Старова гласи „Zeit der Ziegen“, а како преведувач се потпишува Роберто Мантовани. Англискиот превод, "The Time of the Goats", пак, е превод на Кристина Крамер.

Клучен критериум токму романот „Времето на козите“ да биде книжевното дело од кое ќе се ексцерпира корпусот за истражувањето беше податливоста на ексцерпираните примери за овој тип анализа, што значи дека во него се

\footnotetext{
${ }^{2}$ Според „Правописот на македонскиот јазик“ (2017), сите елементи од имињата на градовите, селата, населбите и на маалата се пишуваат со голема почетна буква. Следствено на тоа, правописно точната форма на овој ојконим треба да биде Еврејско Маало, а тоа е случај и со Козар Мало (ibid 45).
} 
застапени имиња кои, несомнено, претставувале предизвик за преведувачите, пред сѐ, поради семантиката и силното апелативно значење на антропонимите во делото, а тоа што посебно го издвојува овој роман се имињата на животните, поконкретно на козите. Во лингвистиката тие се нарекуваат зооними. Иако не се доволно истражувани во рамките на ономастиката, зоонимите од културолошки аспект се исклучително интересни: тие го отсликуваат односот на општеството спрема одреден вид животно или спрема животните воопшто.

Романот „Времето на козите“ раскажува токму за уништувањето на домашните кози - за многумина свети животни во Македонија како дел од Југословенската Федерација (СФРЈ) - кон средината на 50-тите години, но во него се вткаени и приказните за мачните егзодуси на илјадници селани, кои биле повикани, па дури и присилени од Комунистичката партија да се преселат во градовите и да станат дел од градската работничка класа. За да се постигне тоа, комунистичкиот режим наредил да се уништат козите во руралните, а потоа и во урбаните средини и по секоја цена да се спроведе забрзана индустријализација.

Масакрот на козите во романот, пак, е искористен како алегорија што сведочи за сизифовската борба на човекот против уништувачките сили и синдромот на ликвидации, кои се карактеристика на Балканот. Самиот автор ке каже дека козите се еден вид персонификација на слободата и на автономијата, која на овие простори речиси неминовно завршува со трагедија.

Живеејќи со спомените од детството, обвиени од мачните времиња кога режимот се пресметувал со козите, овие благородни животни, кои за народот во руралните, но и во периферните градски подрачја значеле живот, Луан Старова ќе создаде една ниту докрај вистинита ниту сосема фиктивна приказна за историјата на едно семејство што доаѓа од другата страна на езерото, од Подградец. Станува збор за многудетно семејство, чиј татко е интелектуалец со диплома од универзитет на една метропола, но во новата земја - странец, туѓинец, неинтегриран, нееднаков, во незавидна позиција, или како што ќе каже Али Алиу во предговорот кон романот, „каква што беше позицијата на секој Албанец во поранешна Југославија““ (Старова 2014[1993]: 6).

Овој татко, како последица на многу (не)прилики, ќе се најде во Скопје, главниот град на Македонија, која е дел од тогашната југословенска држава, ама среќата ќе му пресуди да се стационира во Козар Маало, во една населба на неписмени. Немајќк друг излез, борејќи се за опстанокот на своето семејство, обидувајќи се на сите начини да ги оддалечи своите најмили од канџите на гладот, купува коза, станува козар, а со тоа станува едно со мнозинството што го опкружува за да биде прифатен како негов составен дел.

Но, „доволно е едно решение (...) на диктаторот за да се дислоцираат градови, население, за да се испишат цели армии, (...) за да се уништат Козите“ (Старова 2014[1993]: 7). А, што претставуваат тие, всушност? Козите се дел од природата, нејзиниот живот и егзистенција. Ако ги снема нив, ќе се повредат законитоста и хармонијата на природата, ќе се изврши насилство врз животниот ритам на целото човештво.

Таткото го претчувствува овој немил развој на настаните, пред кои доаѓањето на козичките во неговото семејство било пречекано со радост, детска 
смеа, надеж... Но, тој бил толку добро информиран што не можел никогаш да биде оптимист. А, неговиот син, нараторот, бил длабоко вознемирен од судбината на козите. Вознемиреноста, стравот и очајот останале во него да тлеат како некое длабоко ехо. И, ако за некого чинот на ликвидирањето на козите е само нешто незначајно, можеби гротескно, дури и смешно, за шестгодишниот Луан тоа е настан што ја определува целата негова иднина, незгасливо жариште што еден ден ќе избие во оган.

Жртвуваните кози никогаш нема да се вратат во Скопје, главниот град на Македонија и во времето на Југославија и по осамостојувањето, исто како што селаните, принудно преселени во градовите, никогаш нема да станат вистинска работничка класа.

Али Алиу соодветно ќе го претстави романот како преплет на една иронична нота на реалноста и една тивка вознемиреност, за да заврши со мислата дека одлуката за уништувањето на козите е доказ дека „од една страна функционира суровоста на законот подигнат во симбол на насилство“, а од друга - „една поставена тишина, библиска за да остане“ (Алиу во предговорот кон Старова 2014[1993]: 8).

Како што козите заземаат централно место во романот на Луан Старова така и нивните имиња ќе бидат главната точка на анализа при ономастичкото набљудување на „Времето на козите“. Фактот што во делото се вклучени и зооними, му дава нова ,димензија“ на истражувањето, зашто нуди и корпус имиња што имаат јасна, „прозирна“ мотивација [описни/сугестивни имиња (сп. Gálová 2011: 2213)]. Со тоа тие носат во себе значење за чие согледување не е потребно поголемо познавање на етимологијата на личните имиња, туку многу повеќе на општествено-политичката ситуација во времето во кое се одвива дејството на романот.

Белка (62)3, Сйалинка (70), подоцна Слобояанка (86) и Гроа (84), се имињата на козите околу кои почнува да се врти животот на семејството Старова. Освен нив, во книгата се споменува и милата и кротка козичка со соодветно име - Мила (96), но и главниот прч на козарот Чанга - Сйалин (73).

Козата Белка најпрво била во сопственост на Чанга, но тој, како благодарност за најголемиот дар што го добил од таткото - писменоста, решава да му возврати со уште еден, за него исто толку скапоцен дар - козичката Белка. На пописот на кози организиран од комунистичката власт, семејството Старова ќе биде запрашано за значењето на името (што, мора да се признае, не е тешко за одгатнување), а мајката ќе одговори дека, освен што е сосем бела, таа е Божји дар за нив, па со неа вечно ќе им биде бел денот (сп. Старова 2014[1993]: 84, 87). Значи, освен описно/сугестивно, Белка во случајов е и желбено име.

Гряа е третата коза во семејството Старова, но нејзиното име не смее да залаже: според зборовите на мајката, таа е вистинска убавица. Но, за да не ја урочат втората козичка - „спасителката Сталинка“ - тие се решаваат да ѝ доделат име што ќе ја скрие таа убавина и ќе ги заштити и неа и Сталинка од уроци (сп. Старова 2014[1993]: 85).

\footnotetext{
${ }^{3}$ Старова 2014[1993]. При првото наведување на еден оним, во загради се дава страницата на која за првпат се среќава.
} 
Името на втората коза, Сйалинка, и нејзиното преименување во Слобояан$\kappa a$ е процес што, самиот по себе, претставува огледало на целата општествено-политичка ситуација во тие години. Многу е интересна, на пример, сцената кога семејството одлучува за тоа кое име е погодно за новото козиче, новата радост и гордост.

Имено, еден од постарите браќа веќе е длабоко завлезен во политиката: од комунистичката страна, секако. Па, иако во духот на традицијата на семејството е на рожбите или на козите новодојденци да им се даваат неутрални имиња, за братот, идниот партиец, доаѓаат предвид само имиња на истакнати комунисти од поновата историја. Тие, разбирливо, најчесто се машки, но братот веднаш наоѓa совршено решение: новата козичка ќе се вика Сйалинка, гордо ќе го носи името на големиот ослободител од Советскиот Сојуз.

Од името никој не е задоволен, најмалку таткото, кој воопшто не е среќен што синот толку се има свртено кон партијата. Но, нема да проговори ништо, па новото козиче и навистина си го добива името Сйалинка.

А, всушност, ние децата и не бевме начисто кој е Сталин, како што не беше начисто до крај и братот партиец кој го предложи името.

Го гледавме Сталина на сликата крај онаа на Тито, над нашите креветчиња, во големата дневна соба што ни служеше како спална. Го гледавме Сталина, со строг поглед, густи веѓи и мустаќи. Верувавме дека таков моќник ќе ја штити нашата коза, нашето семејство...(Старова 2014[1993]: 71)

Ниту Чанга, големиот козар во Козар Маало, не бил воодушевен од името на оваа убава коза. Но, како можел да го каже тоа наглас кога неговиот главен

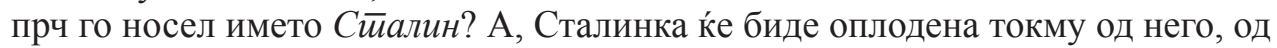
големиот и моќен прч истоименик.

Сепак, најмалку среќен од изборот на името не е ниту таткото ниту Чанга, туку шефот на пописот на кози:

- Луѓе мои, па во ова семејство сѐ се измешало. Каде се чуло и видело коза да носи име на великиот ослободител на народите?! Барем да беше јарец... Не, не, ни јарец, што зборувам. Па вие имате и слика на Сталин. Сталин е нашиот брат што и да се случи. Има разни гласови. Сталин сите нѐ ослободи. Неговото свето име е свето име за сите нас!

(...)

- Името Сталинка на козата може различно да се толкува. Списоците одат до погорните раководства, до федерација. За едно обично име можат да паднат многу глави. Дајте друго име, па сите да бидеме мирни.(Старова 2014[1993]: 85)

Во овој момент на потег бил оној поради кого и настанала целата ситуација, „кумот“ што го избрал името, братот, надежниот партиец, кој одлучува: козата ќе се вика Слобояанка! Очигледно, за него меѓу името Сталин и слободата стоел знакот за еднаквост.

Но, во моментот кога меѓу политичките визии на Тито и оние на Сталин веќе нема да стои овој знак, децата најмногу ќе се уплашат токму за козичката Слободанка, поранешна Сталинка. Целото семејство живее во страв дека сега 
нејзиното првобитно име веќе нема да биде протолкувано како исмевање со Сталин, туку како израз на тврдокорен сталинизам. Тие никако не сакаат да дозволат таа да стане првата жртва на сталинизмот на овој јужен дел од Балканот и тоа поради едно име, едно обично име!

Очекувано, во случајот на Сталинка/Слободанка не станува збор само за транзиција на едно лично име, туку ова преименување е огледало на големите општествено-политички промени што ја зафатиле Македонија во 50-тите години на минатиот век.

А, дали козите, нашите необични главни ликови во овој необичен роман, ќе станат жртви на комунистичкиот режим или ќе се спасат благодарение на нивниот најголем пријател Чанга, останува отворено прашање, но на авторот му е јасно едно: со прогонот на овие благородни животни завршило најубавото време на светот, времето на козите.

Освен зоонимите, интересни за анализа се и антропонимите во одбраното дело, поконкретно имињата на децата. Имено, во тешките времиња низ кои поминувало не само ова туку и многу семејства од овој регион, смртта била секојдневје, а раѓањето празник. По губењето на братче или на сестриче се чекала новата рожба, која во очите на ужалените родители и деца претставувала реинкарнација, воскреснување, ново раѓање на своите починати сакани. Како што растеле, сепак, сѐ потешко било да ја замаскираат болката и да ја ублажат трагедијата.

Во тие мигови на безизлезна состојба, да имаше малку пеницилин или некој друг антибиотик, подруга ќе беше судбината на нашето семејство. Вака сѐ мораше да се решава во големата душа и намаченото тело на мајка ми, таа света заштитница на портите на откорнато семејство кое го имаше проклетството Балканот да му биде татковина...(Старова 2014[1993]: 67)

Поради оваа сурова судбина, таткото не сакал имињата на своите деца да ги врзува за светци, војсководци, политичари или за кои било славни луѓе. Тој им дал имиња што авторот ќе ги нарече „неутрални“ (Старова 2014[1993]: $70)$, но истовремено, се работи за имиња што содржат силна семантика и јасна апелативна слика, па би можеле да се набљудуваат како сугестивни и желбени: Мугрран (67), Лав (68), Свейлина (68), Волја (68), Желба (68).

За жал, желбените имиња нема да имаат магиска моќ што ќе им ја даде на децата судбината посакувана од оние што најмногу ги сакаат - нивните родители.

\section{2. Пристапи за добивање еквиваленти на книжевни антропоними}

Арсова-Николиќ (1998: 13) посочува дека „за да се оствари превод којшто е наполно адекватен на оригиналот, треба да се постигне преводна еквиваленција на повеќе јазични нивоа: на фонолошко, графолошко ортографско, граматичко и на лексичко ниво. Пренесувањето на сопствените имиња (лични и географски) од изворниот јазик во јазикот на преводот е поврзано со првите две од споменатите нивоа“. 
Со оглед на тоа што преведениот текст кај читателите треба да предизвика (барем) слична реакција каква што би предизвикал оригиналниот, преведувачот треба да биде највнимателен при изборот на преведувачкиот пристап токму во случаите кога изворната и целната култура значајно се разликуваат (сп. Koller 2011: 54).

Во тој контекст, во транслатологијата се зборува за два преведувачки пристапа:

I. одомаќинувачки (герм. einbürgernde Übersetzungsmethode) и

II. отуѓувачки пристап (герм. verfremdende Übersetzungsmethode)

(сп. Schleiermacher 1973).

I. Со користењето на одомаќинувачкиот пристап, преведувачот колку што може поверно ги следи нормите на целниот јазик. Колер (Koller 2011: 54-56) зборува за аяайиирачки/йрисиоособувачки йревоя, а шведскиот книжевен теоретичар Гете Клинберг овој метод го нарекува и наџионална аяаййација (Klinberg, цитирано според Touvinen 2011: 27).

Ако преведувачот се одлучи за одомаќинувачкиот пристап, при предавањето на личните имиња, по правило, ги применува следниве пристапи:

1. Користи варијанти на изворното име (алоними) одомаќени во целниот јазик, на пример, Georg - Ѓорйu4.

2. Ги преведува (метономазија), на пр., Theodor - Божсияар, Professor

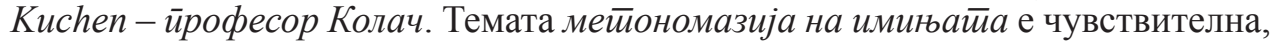
дури и контроверзна, т. е. дали имињата смеат (некогаш) или не смеат (никогаш) да се преведат е прашање околу кое лингвистите не се докрај согласни. A, кога станува збор конкретно за антропонимите, оние за кои ова прашање е, веројатно, најрелевантно се описните/сугестивните имиња.

Што се однесува до самите пристапи, кај одредени лингвисти сликата е многу поразгранета. Така, потпирајќи се на Кригер (Krüger 2004, цитирано според Gálová 2011: 2215-2217), Галова во своите истражувања ги вклучува и следниве пристапи:

3. Антономазија - замена на сопствено име преку опис на неговиот денотат, и тоа најчесто кога референтниот објект не е познат за целната култура. Значи, онимот сосема се изостава, а на негово место стои парафраза. Сепак, со некои еквиваленти од овој тип се парафразира и сосема познат денотат и се употребуваат со речиси иста фреквенција како и личното име (сп. Gálová 2016: 86): Beherrscher des Meeres 'господар/владетел на морето' - Neptun, Das Heilige Land 'Света Земја' - Israel.

4. Креативен трансфер - замена на сопствено име со друго име што му припаѓa на истото семантичко поле (сп. Gálová 2016: 85): мак. С̄̄oūapeв герм. Pfenigov.

5. Супституција - замена на сопствено име со друго име што предизвикува слични конотации или асоцијации (сп. Gálová 2016: 85): Hänsel und Gretel Јованче и Марика.

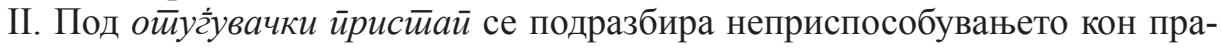
вилата на целниот јазик (сп. Schneider 1985: 4-6). Тој овозможува поверно пренесување на оригиналниот текст, притоа приближувајќи го „духот на из-

\footnotetext{
${ }_{4}^{4}$ За овој преведувачки механизам ќе го користам и терминот адаптација.
} 
ворниот јазик“ кон целната читателска публика (сп. Schleiermacher 1973: 44). Колер (Koller 2011: 54-56) во овој случај зборува за итрансферирачки йревоо.

Кога станува збор за предавањето на личните имиња во рамките на отуѓувачкиот пристап, Галова, повторно потпирајќи се на Кригер (Krüger 2004, цитирано според Gálová 2011: 2215-2217), говори за:

1. Транскрипција/транслитерација - кога фонолошкиот систем на изворниот јазик се заменува со еквивалентниот фонолошки систем на јазикот цел и предадената еквиваленција се постигнува врз основа на исти акустички и артикулациски својства на гласовите и на нивното место во гласовните структури на двата јазика.

2. Транскрипција/транслитерација со коментар - овој начин на предавање може да се оствари на повеќе начини: преку додавање на титулата, професијата, роднинската врска на ликот во целниот текст, потоа преку апозиција со фуснота или со помош на глосар.

3. Транскрипција/транслитерација со адаптација на суфиксот - тука не станува збор само за приспособување кон типичните суфикси за презимињата во македонскиот јазик: -(ов)ски, -(ов) $c к а,-о в,-в a$, туку и за деминутивните суфикси, на пример, -че/-енце, како и за суфиксите за женски имиња, на пример, - иза/-ка.

4. Преземање како цитиран збор - тоа значи преземање на името во неговата оригинална форма, со оригиналното писмо.

Одредени елементи од оригиналниот текст можат, од одредени причини, и да отпаднат во преводот (исйушйање). Ова е најчесто случај кај реалиите, во кои ги вбројуваме и онимите. Испуштањето на онимите не смее да ја засегне разбирливоста на одреден контекст, односно може да дојде предвид ако онимот нема значење за самото дејство или, пак, ако преведувачот експлицитната информација за реалијата ја предава имплицитно (сп. Kujamäki 1998: 88).

\section{1 Германските и англиските еквиваленти на антропонимите во романот „Времето на козите“}

Белка и Грда носат имиња со апелативно значење, кое одразува одредена физичка карактеристика на козата, односно, во случајот на Грда, името служи како заштита од уроци. Роберто Мантовани ги транскрибирал зоонимите, но, како и во случајот на желбените имиња на децата, при првото споменување и ги превел: Belka (die Weiße) (113) 'Белата' (потенцијални преводни решенија би можеле да бидат и: Schneeball 'Снежна топка', Elfenbein 'Слонова коска', Alabaster 'Алабастер'), Grda (die Häßliche) 'Грдата' (113).

Преведувачката на англиски, пак, за Белка дала дури две варијанти: Blanchette (60) ${ }^{6}$, а понатаму Brighty (66) 'Светла'. Козичката Грда на англиски го добила преводниот еквивалент $U g l y(86)$ 'Грда'. Значи, за разлика од Мантовани, кој пристапил кон експликација, Крамер се одлучила за метономазија на имињата.

\footnotetext{
${ }^{5}$ Starova 1999.

${ }^{6}$ Starova 2012.
} 
Сйалинка (92) и на германски и на англиски јазик е транскрибирана како Stalinka (70), што е и очекувано со оглед на тоа што во себе го содржи името на поранешниот лидер на Советскиот Сојуз, Сталин, во женска форма добиена со помош на суфиксот -ка, кој се додава на машкото име (Сйалин-ка), кое, пак, е препознатливо и на германското и на англиското говорно подрачје. Нејзиното преименување во Слобояанка (86) на германски е предадено како Slobodanka (115), со дополнително објаснување при првото споменување die Freie 'Слободната'. На англиски Слободанка е преведена како Liberty (87) 'Слобода'.

Иако не е дел од козичките на семејството Старова, во романот ја среќаваме и козата Мила (96). Мантовани, без дополнително објаснување, ја транскрибирал како Mila (128), а Крамер додава и превод на името кога таа првпат се споменува - Mila, or Sweetheart (100) разг. 'Душа/Срце'. Понатаму ја предава само формално.

Роберто Мантовани антропонимите во преводот на „Времето на козите“ во најголем дел ги транскрибира, но кај дел од нив додава објаснување на семантиката при првото споменување (експликација). Така, последното дете во семејството Старова го добива името $А \bar{z} и м$, а авторот ја наведува и неговата македонска верзија - Муг̄ран (67)7. Роберто Мантовани го предава само македонското име - Mugran, со објаснувањето: von Mugra, die Morgenröte (88) ('од зора'). Во англискиот превод Кристина Крамер пак, го задржува само албанското име - Agim, а го објаснува на следниот начин: which means 'dawn' (67) ('што значи зора').

Желбените имиња Старова ги наведува и на македонски и на албански ја-

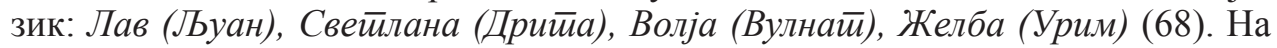
германски, македонските алоними се предадени експликативно: Lav (Löwe) 'Лав', Svetlana (die Lichte) 'Светлост/Светлата', Wolja (Freiheit 'Слобода', веројатно со намера да се избегне фонетска реализација на $v$ како [f] во почетна позиција во германскиот јазик, како кај Volker, Villach, но преведувачот можеби и свесно сакал да ја воспостави блискоста со преводниот еквивалент на ова име во германскиот - Wille 'Волја'), Schelba (Wunsch) 'Желба'.

Интересно е што Мантовани секое кирилско в во преводот на имињата од „Времето на козите“ го транскрибира со латинично $w$, но кај оние што се повообичаени на словенските, но и на пошироките простори, се одлучува за $v$, и со тоа за транслитерацијата како пристап: Лав (68) - Lav (88), Свейлана (88) - Svetlana (88). Причина за ова може да биде фактот што имињата претставуваат голем дел од лексиката, а кога станува збор за нивното предавање од еден јазик на друг, кај нив разликуваме два вида: имиња што се веќе влезени во јазикот на кој се преведува (како, на пр., Лав и Светлана) и имиња што преведувачот допрва треба да ги внесе. Кај првиот тип антропоними се очекува читателот од искуство да знае како би се изговориле, додека кај вториот - преведувачот, барем во овој случај, се одлучил за транскрибирање и преку соодветна модификација на фонетската содржина го доближил изговорот на името што е недоволно познато за читателот.

\footnotetext{
${ }^{7}$ Македонската верзија би можела да биде и Зоран, изведено од зора.
} 


\section{3 Пристапи за добивање еквиваленти на книжевни топоними}

Со цел да не настанат ,лексички дупки“ во преводот од аспект на топонимите, преведувачот може да се одлучи за еден од следниве пристапи за нивно предавање:

1. задржување на оригиналната форма;

2. метономазија:

а. калкирање,

б. полукалкирање;

3. експликација,

(сп. Rossel Steuer 2004).

Кај други автори се говори и за пристапите:

4. адаптација;

5. хиперонимиски еквивалент;

6. хипонимиски/кохипонимиски еквивалент;

7. асоцијативен превод.

1. Во овој процес топонимот директно се презема од оригиналниот текст. Оправдувањето за овој пристап се базира на гледиштето дека топонимите, како, впрочем, и имињата општо, означуваат индивидуални, единствени ентитети или нешта и се разликуваат од другите јазични знаци по тоа што, гледано лингвистички, од нивниот сигнификат не можат да се изделат семантички обележја (сп. Newmark 1981: 70). Тие не содржат конотации или значења, па затоа не треба да се преведуваат. Ако топонимот нема одомаќено соодветство во целниот јазик (егзоним), едноставно се презема во оригиналната форма. ${ }^{8}$

2. И покрај генералниот принцип на задржување на формата на имињата, не може да се побие фактот дека во одредени случаи токму преводот е препорачан, па и неопходен пристап, дури и кога станува збор за топоними. Двата највообичаени процеси на преведување на топонимите се калкирањето и полукалкирањето.

а. Преку калките се предава семантичкото значење на топонимот, со тоа што преведувачот оперира на лексичко ниво, преведувајќи го топонимот член по член, односно збор по збор (герм. Nordsee - мак. Северно Mоре).

б. Кај полукалкирањето, пак, се работи за предавање на сложенки, кај кои едниот елемент се преведува, а другиот се презема директно или само формално се транскрибира/транслитерира. Најчесто станува збор за сложенка составена од лично име и од апелатив, со тоа што личното име се презема, а апелативот се преведува. со оглед на тоа што токму апелативниот, односно денотативниот елемент е транспарентен, на пример: англ. Rocky Mountains мак. Роки Планини, наспрема Карӣесӣu Планини (калка).

И, додека за метономазијата се дискутира како за „контроверзен“ пристап кај некои видови топоними, кај други таа претставува решение што логично следува. Како пример ќе бидат наведени неколку имиња на објекти ексцер-

\footnotetext{
8 Во контекст на овој труд, под нейревеяување на йойонимииее нема да се подразбира нивно задржување во оригиналната форма во буквалната смисла на зборот. Имено, со оглед на различните писма на контрастираните јазици, а аналогно на анализата на предавањето на антропонимите, ретко може да стане збор за директно преземање на изворната форма на топонимот без негова графиско-ортографска адаптација.
} 
пирани од романот „Времето на козите“, кај кои и германскиот и англискиот преведувач се одлучиле за калкирање: Дом на Армијай - Haus der Armee 'Куќа на Армијата' - Army Club 'Клуб на Армијата', Женска гेимназија Mädchengymnasium 'Гимназија за девојчиња'-Girls' High School 'Гимназија за девојки', Музеј на револуиијайа9 - Revolutionsmuseum 'Музеј на Револуцијата' - Museum of the Revolution 'Музеј на Револуцијата'. Овие еквиваленти и нивната функционалност не оставаат простор за сомнеж во тоа дали преводот смее да биде опција. ${ }^{10}$

3. Терминот ексйликаиија Росел Штојер (Rossel Steuer 2004: 82) го употребува пишувајќи за оние топоними што преведувачот ги „дообјаснува“ за експлицитно да пренесе одредена информација до целниот читател што е (имплицинтно) веќе застапена во оригиналниот текст. Имено, топонимите, како и сите имиња, освен денотативна, можат да имаат и конотативна функција. Ако, на пример, читателот не ја препознава конотацијата што ја носи дадениот топоним во себе, задача на преведувачот е да му ја доближи (сп. Newmark 1981: 72). Ова може да го направи, на пример, со кратка забелешка. Постојат и случаи кога одредени топоними, генерално, воопшто не се познати во целната култура, па преведувачот може и да додаде генерична компонента, давајќи му, притоа, јасна денотација на топонимот (сп. Newmark 1981: 72). Експликацијата, значи, служи за олеснување на текот на читањето, односно на разбирливоста на текстот.

4. Слично како кај антропонимите, разгранетоста на пристапите во предавањето на топонимите е различна кај секој автор. Така, Маркштајн (Markstein 1998: 291) зборува и за аналог̃ија - кога реалијата се заменува со соодветен елемент/феномен од целниот јазик, односно од целната култура (мак. йарламен $\bar{u}$ - герм. Bundestag). Со овој пристап, меѓутоа, се ризикува губење на одредени белези и карактеристики на оригиналниот културен или локален колорит (сп. Kujamäki 1998: 85).

5. Кај хиперонимискиот еквивалент, пак, оригиналниот топоним, во случајов хипоним, се заменува со термин што му е надреден - хипероним (герм. Philippinengraben - мак. Филийинско Море). Како и кај адаптацијата, и преку овој вид трансфер се губат одредени конкретни, како и специфични културни белези на оригиналниот поим, што го засега и целокупниот приказ на просторот каде што се одигрува дејството (сп. Kujamäki 1998: 86).

6. Преку кохипонимискиот еквивалент топонимот се заменува со негов кохипоним ${ }^{11}$, а кај хипонимискиот еквивалент, соодветно, со хипоним (сп. Kujamäki 1998: 86). Во споредба со хиперонимискиот еквивалент, овие типови трансфер се когнитивно поизискувачки и уште „поризични“, па преведува-

\footnotetext{
${ }_{9}^{9}$ Музејна Револуиијайа (,Ако од целиот назив се употреби само еден збор, тој се пишува со голема почетна буква“, „Правопис на македонскиот јазик“ 2017: 51).

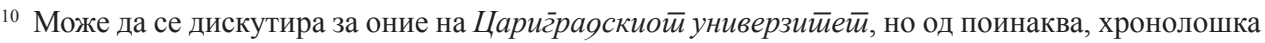
историска причина. Имено, познато е дека Истанбул во текот на своето постоење сменил многу имиња, а интересно е што на германски е предаден како Universität von Istanbul, додека преве-

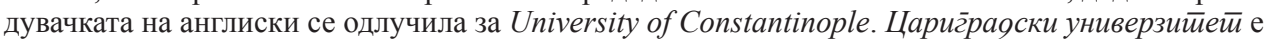
името што до 1930 г. го носел денешниот Истанбулски универзитет, па, се чини, оваа преведувачка била посвесна за хронолошките промени на името на универзитетот, односно на градот.

${ }^{11}$ Кохийоним - хипоним што заедно со други хипоними му е подреден на даден хипероним.
} 
чот би требало да се определи за нив само во контекст во кој не би настанале недоразбирања.

7. При асоцијативниот превод избива во преден план значењето на топонимот, и тоа контекстуалното. Значи, еквивалентот на топонимот и лексички и формално значително се разликува од оригиналниот (сп. Kujamäki 1998: 88). Со тоа овој трансфер целосно му припаѓа на адаптирачкиот пристап, дури и по цена на нарушување на локалниот колорит (Градот на Светлината наместо Париз).

Како што е посочено и кај предавањето на антропонимите (в. т. 2), и топонимите, под одредени услови, можат да се изостават во преводот.

\section{1 Германските и англиските еквиваленти на топонимите во романот „Времето на козите“}

Роберто Мантовани во германскиот превод на „Времето на козите“ ојконимите Еврејско маало (10) [sic!] и Козар маало (23) [sic!] ги превел како Judenviertel (8) 'Кварт на Евреите', односно Hirtenviertel (25) 'Кварт на козарите' (метономазија). Со оглед на тоа што сите овие ојконими се составени од автосемантички придавки и именки што се релевантни за ојконимите, а во случајот со овој роман, и за приказната, може да се заклучи дека токму преводот е соодветно решение. Следствено на тоа, и англиската преведувачка Кристина Крамер постапила на ист начин - Jewish Quarter (5) 'Еврејски Кварт', Goathead Quarter 'Козарски Кварт’ (19).

Од анализата на дромонимите и на урбанонимите (сп. Kamianets 2000: 48), во романот „Времето на козите“ заклучуваме дека Мантовани најчесто пристапува кон експликација или кон метономазија, а кон метономазија тежнее и Крамер. Така, урбанонимот Kaлe (9) во германскиот превод гласи Festung Kale (5) 'тврдина Кале', а во англискиот - the fortress - called the Kale or "citadel”, (4) 'тврдината - наречена Кале или цитадела'.

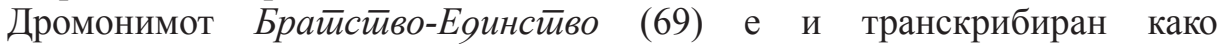
Bratstwo-Edinstwo, но во загради е и преведен - Brüderlichkeit-Einigkeit (91) 'Братство-Единство', а на англиски, овој автопат е преведен како Brotherhood and Unity Highway (69) 'автопат Братство и Единство'.

Еквивалентите на дромонимот Дрвен мосӣ (9) гласат Holzbrücke (5) 'Дрвен мост', односно Wooden Bridge (3) 'Дрвен мост', а за разлика од англиски-

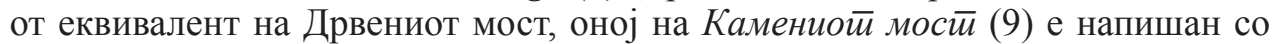
мали почетни букви - stone bridge (4) 'камен мост', со што оваа именска синтагма графиски ја губи „димензијата“ на име. Германскиот еквивалент гласи Steinbrücke (6) 'Камен мост'.

Урбанонимот Бурмали иамијайа (9) ја пренесува нејзината прстенеста форма ('како бурма'), што не е предадено во германскиот еквивалент Burmali-Moschee (6) 'Бурмали-џамија', каде што е преведен само генеричкиот елемент (полукалка), но значењето му е пренесено на англискиот читател - Burmali, or Spiral, Mosque (3) 'Спирална џамија'. 


\section{4 Заклучок}

Во оваа статија најпрво беше истражена интенцијата и мотивацијата на авторот за изборот на одреден зооним/антропоним, при што заклучивме дека ниедно име употребено во едно книжевно дело не е случајно избрано од писателот, односно дека секој разгледуван оним од делото ја отсликува авторовата мотивација и интенција, што значи дека ја има моќта да карактеризира, а не само да идентификува, како што е случај со онимите од постојната реалност.

Кога станува збор за механизмите на предавање на онимите при трансфер од еден во друг јазик, во анализираните преводи наидовме на транскрипција

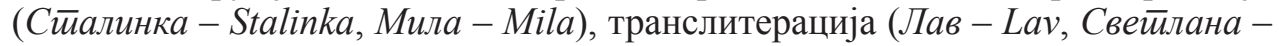
Svetlana), експликација (Белка-Belka (die Weiße), Mила-Mila, or Sweetheart), а во случајот на англискиот превод, и метономазија (Слобояанка - Liberty, авйойай Брайсииво-Еяинстиво - Brotherhood and Unity Highway).

Од корпусот може да се заклучи дека преведувачите често не можат да применат само еден пристап на предавање на онимите, ако ја имаат функционалноста на преводот како главна и најважна цел. Консеквентноста и доследноста на преведениот текст се многу значајни, еквивалентите треба да се теоретски и практично издржани, но преведувачите предимно треба да се стремат кон изнаоѓање оптимална рамнотежа меѓу задржувањето и почитувањето на интенциите на авторот и овозможувањето непречен тек на читањето за целната публика. Нивната задача е, значи, многу одговорна и нималку лесна, изискува промисленост и темелна анализа на самиот оригинал, но токму внимателниот пристап кон онимите како културолошки реалии може да придонесе за создавање на еден квалитетен превод.

\section{Библиографија}

Арсова-Николиќ, Л. (1998). Сӣрански имиња. Аوайт̄ација и йранскрийщија со Речник на гееографски имиґа, 7-15. Скопје: МАТИЦА МАКЕДОНСКА. [Arsova-Nikoliḱ, L. (1998). Stranski iminja. Adaptacija i transkripcija so Rečnik na geografski iminja, 7-15. Skopje: MATICA MAKEDONSKA.]

Коробар-Белчева, М. (2006). Личните имиња во функција на уметничката порака.

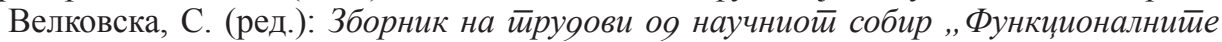
сийлови во макеgонскиой јазик". 13 - 14 април 2006, 85-91. Скопје: Институт за македонски јазик „Крсте Мисирков“. [Korobar-Belčeva, М. (2006). Ličnite iminja vo funkcija na umetničkata poraka. Velkovska, S. (red.): Zbornik na trudovi od naučniot sobir ,,Funkcionalnite stilovi vo makedonskiot jazik“. 13 - 14 april 2006, 85-91. Skopje: Institut za makedonski jazik „Krste Misirkov“.]

Ризовски, Ж. (2002). Стилската функција на ономастичката лексика во македонската поезија и проза. Аргировски, М. (ред.): Макеgонистиика, 3-71. Скопје: Институт за македонски јазик „Крсте Мисирков“. [Rizovski, Ž. (2002). Stilskata funkcija na onomastičkata leksika vo makedonskata poezija i proza. Argirovski, M. (red.): Makedonistika, 3-71. Skopje: Institut za makedonski jazik „Krste Misirkov“.]

Старова, Л. (2014[1993]). Времейо на козииее. Скопје: АД ВЕРБУМ. [Starova, L. (2014[1993]). Vremeto na kozite. Skopje: AD VERBUM.] 
Gálová, S. (2016). Verfahren der Wiedergabe von Eigennamen im Sprachenpaar DeutschSlowakisch am Beispiel von literarischen Texten. Baudisch, S. / Bergien, A. / Greule, A. / Hengst, K. / Kremer, D. / Kremer, D./ Patzold, S.: Namenkundliche Informationen (NI). Schwerpunktthema: Namen und Übersetzung, 77-93. Leipzig: Leipziger Universitätsverlag.

Kamianets, W. (2000). Zur Einteilung der deutschen Eigennamen. Grazer Linguistische Studien. Band 54, 41-58. Graz: Institut für Sprachwissenschaft der Universität Graz.

Kohlheim, V. (2017). Kohlheim, Volker: Toponyme in der Literatur: Ein kognitivischer Ansatz. Dunker, A. / Stolz, T. / Warnke I. H. (Hrsg.): Benennungspraktiken in Prozessen kolonialer Raumaneignung, 352-364. Berlin/Boston: Walter de GruyterGmbH.

Koller, W. (2011). Einführung in die Übersetzungswissenschaft. Tübingen: A. Francke Verlag, 2011.

Krüger, D. (2004). Eigennamen in der literarischen Übersetzung; dargestellt am Beispiel von Übersetzungen von J.K. Rowlings Harry Potter. Namenkundliche Informationen, 141-163. H. 85/86.

Kujamäki, P. (1998). Deutsche Stimmen der Sieben Brüder: Ideologie, Poetik, und Funktionen literarischer Übersetzung. Frankfurt am Main: Peter Lang GmbH (Nordeuropäische Beiträge aus den Human- und Gesellschaftswissenschaften; 18).

Markstein, E. (1998). Realia. Snell-Hornby, M. (Hrsg.): Handbuch Translation, 288-291. Tübingen: Stauffenburg.

Newmark, P. (1981). Approaches to Translation. Oxford: Pergamon (Language Teaching Methodology Series).

Rosell Steuer, P. (2004).... ein weites Feld? Zu Übersetzungstheorie und Übersetzungpraxis anhand der Kulturspezifika in fünf Übersetzungen des Romans „Ein weites Feld" von Günter Grass. Stockholm: Almqvist \& Wiksell International.

Schleiermacher, F. (1973). Über die verschiedenen Methoden des Übersetzens. Störig, Hans Joachim (Hrsg.): Das Problemdes Übersetzens, 38-70. Darmstadt:Goverts. Zum ersten Mal 1813 als Vortrag veröffentlicht.

Schneider, M. (1985). Zwischen Verfremdung und Einbürgerung. Germanischromanische Monatsschrift 66, 1-12.

Simoska, S. (2016). Luan Starova auf Deutsch - ein literarischer Balken zum interkulturellen Austausch mit dem Balkan. Mario de Matteis (Hrsg.): Übersetzung, Literatur und Kultur als Brücken zur interkulturellen Kommunikation, IX. Konferenz der Germanistischen Abteilung in Tirana Tirana, 5. Mai 2015, 122-132. Tirana: Departamenti i gjuhës gjermane, Universiteti i Tiranës.

Šimunovuč, P. (1976). Ime u funkciji književnog dela, 242. Onomastica jugoslavica. Zagreb. Starova, L. (1999). Zeit der Ziegen. Übersetzt von Roberto Mantovani. Zürich: Unionsverlag.

Starova, L. (2012). The Time of the Goats. Translated by Christina E. Kramer. Madison: The University of Wisconsin Press.

Touvinen, S.(2011). Eigennamen und andere Realienbezeichnungen beim Übersetzen eines deutschen Kinderbuchs ins Finnische. Am Beispiel von Rico, Oskar und die Tieferschatten von Andreas Steinhöfel. Magisterarbeit. Universität Jyväskylä: Institut für moderne und klassische Sprachen - Deutsche Sprache und Kultur.

Gálová, S. (2011). Einbürgerung vs. Verfremdung - Wiedergabe der literarischen Namen in den letzten 50 Jahren“. Actes del XXIV Congrés Internacional d'ICOS sobre Ciències Onomàstiques. Достапно на: http://www.gencat.cat/llengua/BTPL/ICOS2011/211.pdf [Пристапено на: 11.11.2021] 